\title{
PENGARUH PENGUNGKAPAN TANGGUNG JAWAB SOSIAL TERHADAP KOEFISIEN RESPON LABA
}

\author{
Muhammad Nurkholis \\ Carmel Meiden* \\ Program Studi Akuntansi, Institut Bisnis dan Informatika Kwik Kian Gie, \\ J1. Yos Sudarso Kav. 87, Jakarta 14350
}

\begin{abstract}
The purpose of this research is to measure the influence of disclosure corporate social affected to earnings response coefficients, especially in companies listed in Indonesia Stock Exchange in the year 2007-2011. Corporate Social Responsibility (CSR) disclosures is the independent variable of this research, with leverage and size as control variables. Measurement of CSR disclosures is based on the index Global Reporting Initiative (GRI) G3 2006. Object research used 7 companies in the Indonesia Stock Exchange (IDX) that have sustainability reports in the period 2007-2011, the end of the fiscal year or fiscal month December and has a publication date of the financial statements, with the total sample for five years as many as 35. Analysis technique used are F-Test, $t$-Test, and $R^{2}$, and multiple regression analysis. CSR disclosures have positif effect to earnings response coefficient not significantly on $\alpha=5 \%$ both model I and model II. In summary, the result of this research not found proper evidence that CSR disclosures has negative effect to earnings response coefficient.
\end{abstract}

Keyword: Corporate Social Responsibility Disclosure, Earnings Response Coefficient, GRI

\begin{abstract}
Abstrak
Tujuan dari penelitian ini adalah untuk menguji apakah pengungkapan tanggung jawab sosial perusahaan berpengaruh terhadap koefisien respon laba khususnya pada perusahaan yang terdaftar dalam Bursa Efek Indonesia pada tahun 2007-2011. Tanggung jawab sosial perusahaan merupakan variabel independen dalam penelitian ini, dengan leverage dan ukuran perusahaan sebagai variabel kontrol. Pengukuran atas Corporate Social Responsibility (CSR disclosure) didasarkan pada indeks Global Reporting Initiative (GRI) G3 2006. Objek penelitian ini menggunakan 7 perusahaan di Bursa Efek Indonesia (BEI) yang mengeluarkan laporan berkelanjutan periode 2007-2011, akhir tahun buku atau fiskal bulan Desember dan memiliki tanggal publikasi laporan keuangan, dengan total sampel selama lima tahun sebanyak 35. Teknik analisis yang digunakan adalah pengujian keberartian model (Uji F), pengujian koefisien regresi (Uji t), dan koefisien dererminasi $\left(\mathrm{R}^{2}\right)$, serta analisis regresi linier berganda dengan uji asumsi klasik. CSR berpengaruh positif terhadap koefisien respon laba secara tidak signifikan pada $\alpha=5 \%$ baik model I dan model II. Berdasarkan hasil analisis tersebut, tidak ditemukan cukup bukti bahwa pengungkapan tanggung jawab sosial berpengaruh negatif terhadap koefisien respon laba.
\end{abstract}

Kata kunci: Pengungkapan Tanggung Jawab Sosial, Koefisien Respon Laba, GRI

\footnotetext{
* Alamat kini:Institut Bisnis dan Informatika Kwik Kian Gie, Jln Yos Sudarso Kav. 87 Sunter , Jakarta 14350 Penulis untuk Korespondensi: Telp. (021) 65307062 Ext. 806. E-mail: carmel.meiden@kwikkiangie.ac.id
} 


\section{Pendahuluan}

$\mathrm{P}$ erkembangan Corporate Social Responsibility (CSR) sudah menjadi bagian dalam orientasi bisnis perusahaan. CSR dilandasi oleh pemikiran bahwa keberadaan suatu perusahaan tidak lepas dari lingkungan sekitarnya. Pimpinan eksekutif global yang percaya bahwa menangani tanggung jawab sosial perusahaan adalah penting untuk profitabilitas perusahaan mereka (Simms 2002). Sejarah perkembangan akuntansi yang berkembang pesat setelah terjadi revolusi industri di Inggris (1760-1860), menyebabkan pelaporan akuntansi lebih banyak digunakan sebagai alat pertanggungjawaban kepada pemilik modal sehingga mengakibatkan orientasi perusahaan lebih berpihak kepada pemilik modal. Berpihaknya perusahaan kepada pemilik modal mengakibatkan perusahaan melakukan eksploitasi sumber-sumber alam dan masyarakat sosial secara tidak terkendali sehingga mengakibatkan kerusakan lingkungan alam dan pada akhirnya mengganggu kehidupan manusia, maka itu CSR menekankan bahwa tanggung jawab perusahaan bukan sekedar pada kegiatan ekonomi, yaitu hanya menciptakan laba demi kelangsungan usaha, melainkan juga mempunyai tanggung jawab kepada lingkungan dan kehidupan sosial sekitarnya.

Bahkan dalam masyarakat internasional isu lingkungan pada saat banyak perusahaan menjadi semakin berkembang, maka saat itu pula kesenjangan sosial dan kerusakan lingkungan sekitarnya dapat terjadi, karena itu muncul pula kesadaran untuk mengurangi dampak negatif ini. Banyak perusahaan swasta kini mengembangkan apa yang disebut CSR. Penerapan CSR tidak lagi dianggap sebagai cost, melainkan investasi perusahaan (Erni, 2007 dalam Sutopoyudo, 2009).

Etty Murwaningsari (2009) mengatakan informasi laba merupakan salah satu bagian dari laporan keuangan yang banyak mendapat perhatian. Studi yang dilakukan oleh Beaver dkk (1979) dalam Etty Murwaningsari (2009) menunjukkan bahwa laba memiliki kandungan informasi yang tercermin dalam harga saham. Sedangkan Lev dan Zarowin (1999) dalam Etty Murwaningsari (2009) menggunakan Earnings Response Coefficient (ERC) sebagai alternatif untuk mengukur value relevance informasi laba. Rendahnya ERC menunjukkan bahwa laba kurang informatif bagi investor untuk membuat keputusan ekonomi.

Dampak dari tuntutan masyarakat tersebut perusahaan mulai memperhatikan pelaporan yang meliputi aspek keuangan, aspek sosial, dan aspek lingkungan, yang bisa disebut dengan triple bottom line. Sehingga memunculkan konsep akuntansi yang baru menggantikan konsep akuntansi tradisional. Dengan pusat perhatian perusahaan hanya terbatas kepada stockholders dan bondholders, yang secara langsung memberikan kontribusinya bagi perusahaan, sedangkan pihak lain sering diabaikan.

Menurut Andreas Lako (2011) Corporate Social Responsibility (CSR) juga dianggap sebagai konsep akuntasi yang baru adalah transparansi pengungkapan sosial atas kegiatan atau aktivitas sosial yang dilakukan oleh perusahaan, dimana transparansi informasi yang diungkapkan tidak hanya transparansi keuangan perusahaan, tetapi perusahaan juga diharapkan mengungkapkan informasi mengenai dampak sosial dan lingkungan hidup yang diakibatkan aktivitas perusahaan.

Pengambilan keputusan ekonomi hanya dengan melihat kinerja keuangan suatu perusahaan, saat ini sudah tidak relevan lagi. Eipstein dan Freedman (1994) dalam Retni Retno Anggraini (2006), menemukan bahwa investor individual tertarik terhadap informasi sosial yang dilaporkan dalam laporan tahunan. Untuk itu dibutuhkan suatu sarana yang dapat memberikan informasi 
mengenai aspek sosial, lingkungan, dan keuangan secara sekaligus. Sarana tersebut dikenal dengan nama laporan keberlanjutan atau disebut dengan sustainability reporting.

Dari perspektif ekonomi, perusahaan akan mengungkapkan suatu informasi jika informasi tersebut akan meningkatkan nilai perusahaan (Verecchia, 1983 dalam Sayekti dan Wondabio, 2007). Dengan menerapkan CSR, diharapkan perusahaan akan memperoleh legitimasi sosial dan memaksimalkan kekuatan keuangannya dalam jangka panjang (Kiroyan, 2006 dalam Sayekti dan Wondabio, 2007). Hal ini mengindikasikan bahwa perusahaan yang menerapkan CSR mengharapkan akan direspon positif oleh para pelaku pasar.

Diharapkan bahwa investor mempertimbangkan pengungkapan tanggung jawab sosial yang diungkapkan dalam laporan tahunan perusahaan, sehingga dalam pengambilan keputusan investor tidak semata-mata mendasarkan pada informasi laba saja. Pengungkapan tanggung jawab sosial diharapkan memberikan informasi tambahan kepada para investor selain dari yang sudah tercakup dalam laba akuntansi.

Dengan demikian, penelitian ini memprediksi bahwa pengaruh tingkat pengungkapan tanggung jawab sosial dalam laporan tahunan perusahaan terhadap ERC adalah negatif. Hal ini konsisten dengan prediksi yang dilakukan oleh Widyastuti (2002) dalam Sayekti dan Wodabio (2007) yang memprediksi luas pengungkapan sukarela berpengaruh negatif terhadap ERC, namun tidak didukung oleh hasil penelitian empirisnya yang justru menunjukkan pengaruh yang positif dan signifikan.

\section{Teori Pensinyalan}

$\begin{array}{lrr}\quad \text { Para } & \text { Investor } & \text { memanfaatkan } \\ \text { informasi } & \text { publikasian: } & \text { pengumuman, } \\ \text { konferensi } & \text { pers, dan filing kepada regulator }\end{array}$ guna pengambilan keputusan ekonomi. Jaswadi (2004), teori signaling dalam sains komunikasi digunakan dalam disiplin sains akuntansi untuk menjelaskan dan memprediksi pola perilaku komunikasi manajer kepada publik. Teori signaling dalam akuntansi salah satu fungsinya untuk menilai adanya informasi privat, akan tetapi para investor masih tetap mempunyai informasi privat yang memuat nilai perusahaan sebenarnya.

Terkadang informasi privat mengindikasikan bahwa nilai perusahaan lebih tinggi dari yang terefleksikan dalam harga saham saat ini. Sebagai contoh: (1) manajer mempunyai informasi bahwa laba jangka panjang akan lebih tinggi dari ekspektasi pasar: (2) manajer mengetahui bahwa arus kas masa depan perusahaan tidak terlalu bervolatilitas sehingga dapat menurunkan risiko sistematik (beta). Manajer dari perusahaan yang berkinerja baik akan terdorong untuk melakukan pensinyalan harapan tersebut dan manajer dari perusahaan yang memiliki berita netral juga akan terdorong untuk melaporkan berita baik (good news) sehingga mereka tidak dicurigai berkinerja buruk. Jaswadi (2004) menyatakan pengungkapan langsung tidak mungkin dilakukan, manajer dapat mengungkapkan signal tertentu bahwa harga saham underpriced.

\section{Pengungkapan Corporate Social Responsibility (CSR)}

Corporate social responsibility (CSR) merupakan komitmen sosial dari perusahaan sebagai bentuk kepedulian perusahaan atas masyarakat dan juga kelestarian lingkungan serta tanggung jawab terhadap kesejahteraan tenaga kerja perusahaan di dalam praktek bisnis perusahaan.

Para investor mulai mempertimbangkan kegiatan CSR perusahaan. Ini mengindikasikan bahwa investor mengapresiasi informasi CSR yang diungkapkan 
dalam laporan tahunan perusahaan (Sayekti dan Wondabio, 2007). Informasi yang diungkapkan dalam laporan tahunan dapat dikelompokkan menjadi pengungkapan wajib (mandatory disclosure) dan pengungkapan sukarela (voluntary disclosure atau CSR disclosure). Dengan menerapkan CSR, diharapkan perusahaan akan memperoleh legitimasi sosial dan memaksimalkan kekuatan keuangannya dalam jangka panjang.

\section{Earnings Response Coefficient (ERC)}

Penyajian Laba dalam laporan keuangan dan digunakan bagi para pengguna laporan keuangan menjadi hal yang penting baik bagi para peneliti, praktisi, dan juga otoritas pembuat kebijakan. Banyak model equity valuation yang hanya menggunakan expected earnings sebagai variabel eksplanatori (Lev, 1989) dalam Sayekti dan Wondabio (2007). Namun demikian, earnings itu sendiri memiliki keterbatasan yang mungkin dipengaruhi oleh asumsi perhitungan dan juga kemungkinan manipulasi yang dilakukan oleh manajemen perusahaan, sehingga dibutuhkan informasi lain selain laba untuk memprediksi return saham perusahaan.

Scott (2009) mendefinisikan earnings response coefficient (ERC) sebagai berikut: "An earnings response coefficient measures the extent of a security's abnormal market return in response to the unexpected component of reported earnings of the firm isuuing that security." (Suatu koefisien respon laba mengukur tingkat dari suatu pengembalian pasar yang abnormal dari surat berharga/efek sebagai jawaban atas komponen yang tak diharapkan dari pendapatan yang dilaporkan oleh perusahaan yang mengeluarkan surat berharga/efek tersebut).

$$
\text { Menurut Mayangsari }
$$

Penelitian ERC dapat dikelompokkan menjadi :1) penelitian yang melihat faktor-faktor yang mempengaruhi ERC; 2) penelitian yang berhubungan dengan keinformatifan ERC
(Chandrarin, 2001). Penelitian yang dilakukan ini tergolong dalam penelitian yang menguji faktor-faktor yang mempengaruhi ERC.

Ada beberapa hal yang menyebabkan respon pasar yang berbeda- beda terhadap laba, yaitu adalah persistensi laba, beta, struktur permodalan perusahaan, kualitas laba, growth opportunities, dan informativeness of Price (Scott, 2003). Nilai ERC diprediksi lebih tinggi jika laba perusahaan lebih persisten di masa depan. Demikian juga jika kualitas laba semakin baik, maka diprediksi nilai ERC akan semakin tinggi. Beta mencerminkan risiko sistematis. Investor akan menilai laba sekarang untuk memprediksi laba dan return di masa yang akan datang. Jika future return tersebut semakin berisiko, maka reaksi investor terhadap unexpected earnings perusahaan juga semakin rendah. Dengan kata lain, jika beta semakin tinggi maka ERC akan semakin rendah (Scott, 2009). Struktur permodalan perusahaan juga berpengaruh terhadap ERC. Peningkatan laba (sebelum bunga) bagi perusahaan yang highlevered berarti bahwa perusahaan semakin baik bagi pemberi pinjaman dibandingkan bagi pemegang saham. Oleh karena itu, perusahaan yang high levered memiliki ERC yang lebih rendah dibandingkan dengan perusahaan yang low levered (Scott, 2009). Perusahaan yang memiliki growth opportunities diharapkan akan memberikan profitabilitas yang tinggi di masa datang, dan diharapkan laba lebih persisten. Dengan demikian, ERC akan lebih tinggi untuk perusahaan yang memiliki growth opportunities (Scott, 2009). Faktor lain juga mempengaruhi respon pasar terhadap laba adalah informativeness dari harga pasar itu sendiri. Biasanya informativeness harga pasar tersebut diproksi dengan ukuran perusahaan, karena semakin besar perusahaan semakin banyak informasi publik yang tersedia mengenai perusahaan tersebut relatif terhadap perusahaan kecil. Semakin tinggi informativeness harga saham, maka kandungan informasi dari laba akuntansi 
semakin berkurang. Oleh karena itu, ERC akan semakin rendah jika informativeness harga saham meningkat (atau jika ukuran perusahaan meningkat) (Scott, 2009:158-159). Earnings response coefficients merupakan koefisien yang diperoleh dari regresi antara proksi harga saham dan laba akuntansi. Proksi harga saham yang digunakan adalah cumulative abnormal return (CAR), sedangkan proksi laba akuntansi adalah unexpected earnings (UE) (Cho dan Jung, 1991 dalam Widiastuti, 2002). Dengan kata lain, ERC merupakan koefisien sensitifitas perubahan harga saham terhadap perubahan laba akuntansi (Beaver, 1998 dalam Widiastuti, 2002).

Secara umum, hubungan antara tingkat pengungkapan informasi yang dilakukan oleh perusahaan dengan kinerja pasar perusahaan masih sangat beragam. Secara teoritis, ada hubungan positif antara pengungkapan (Lang dan Lundholm, 1993 dalam Sayekti dan Wondabio, 2007). Laporan tahunan adalah salah satu media yang digunakan oleh perusahaan untuk berkomunikasi langsung dengan para investor. Pengungkapan informasi dalam laporan tahunan yang dilakukan perusahaan diharapkan dapat mengurangi asimetri informasi dan juga mengurangi agency problems (Healy dan Palepu:408-410, dalam Sayekti dan Wondabio:2007). Berbagai penelitian telah menguji perbedaan Koefisien Respon Laba terhadap pengumuman laba dengan didasarkan pada premis bahwa informativeness of earnings akan semakin besar ketika terdapat ketidakpastian mengenai prospek perusahaan di masa datang (Widiastuti, 2002). Hal ini berarti bahwa semakin tinggi ketidakpastian prospek perusahaan di masa mendatang, maka ERC semakin tinggi. Diharapkan jika perusahaan melakukan pengungkapan informasi dalam laporan tahunannya dapat mengurangi ketidakpastian tersebut. Dengan demikian pengungkapan informasi akan menurunkan ERC.

Pengungkapan sukarela menunjukkan bahwa tingkat pengungkapan yang lebih tinggi berasosiasi dengan kinerja pasar yang lebih baik (yang diukur dengan return saham). Lang dan Lundholm (1993:252) dalam Sayekti dan Wondabio (2007) menggunakan korelasi laba dan return saham perusahaan sebagai proksi asimetri informasi. Hal ini konsisten dengan motif adverse selection (Lang dan Lundholm, 1993 dalam Sayekti dan Wondabio, 2007). Korelasi laba dan return saham yang rendah mengindikasikan bahwa informasi laba hanya memberikan sedikit informasi tentang nilai perusahaan yang menunjukkan bahwa masih terdapat asimetri informasi yang tinggi. Pengungkapan tersebut bertujuan mengurangi asimetri informasi terutama pada perusahaan yang memiliki korelasi earning/returns yang rendah. Dengan demikian, Lang dan Lundholm (1993) dalam Sayekti dan Wondabio (2007) dalam menyatakan adanya hubungan negatif antara korelasi earnings/returns (ERC) dengan tingkat pengungkapan.

Perbedaan Koefisien Respon Laba terhadap pengumuman laba dengan didasarkan pada premis bahwa informativeness of earnings akan semakin besar ketika terdapat ketidakpastian mengenai prospek perusahaan di masa dating (Widiastuti, (2002). Hal ini berarti bahwa semakin tinggi ketidakpastian prospek perusahaan di masa datang, maka ERC semakin tinggi. Diharapkan jika perusahaan melakukan pengungkapan informasi dalam laporan tahunannya dapat mengurangi ketidakpastian tersebut. Dengan demikian pengungkapan informasi akan menurunkan ERC.

Penelitian Lang dan Lundholm (1993) dalam Widiastuti (2002) mengenai pengungkapan sukarela menunjukkan bahwa tingkat pengungkapan yang lebih tinggi berasosiasi dengan kinerja pasar yang lebih baik (yang diukur dengan return saham). Lang et al (1993) dalam Widiastuti (2002) menggunakan korelasi laba dan return saham perusahaan sebagai proksi asimetri informasi. Hal ini konsisten dengan motif adverse selection (Lang et al, 1993 dalam Widiastuti, 
2002). Korelasi laba dan return saham yang rendah mengindikasikan bahwa informasi laba hanya memberikan sedikit informasi tentang nilai perusahaan yang menunjukkan bahwa masih terdapat asimetri informasi yang tinggi. Pengungkapan tersebut bertujuan mengurangi asimetri informasi terutama pada perusahaan yang memiliki korelasi earning/returns yang rendah. Dengan demikian, Lang et al (1993) menyatakan adanya hubungan negatif antara korelasi earnings/returns (ERC) dengan tingkat pengungkapan.

Pengujian empiris atas pengaruh luas pengungkapan sukarela dalam laporan tahunan terhadap Earning Response Coefficient (ERC) (Widiastuti, 2002). Menemukan adanya pengaruh positif signifikan dari luas pengungkapan sukarela terhadap ERC baik dari model I maupun model II, hal ini tidak sesuai dengan prediksi Widiastuti (2002) akan pengaruh negatif luas pengungkapan sukarela terhadap earning response coefficient (ERC). Sedangkan Sayekti dan Wondabio (2007) dalam penelitiannya menemukan bukti empiris bahwa CSR disclosure berpengaruh negatif terhadap ERC pada model II, sesuai dengan penelitian Lang et al (1993). Untuk model I. Sayekti dan Wondabio (2007) tidak dapat menemukan bukti bahwa CSR disclosure berpengaruh negatif terhadap ERC.

H1: Pengungkapan Tanggung jawab sosial berpengaruh negatif terhadap kualitas respon laba.

\section{Metodologi Penelitian}

Objek yang digunakan dalam penelitian ini adalah keseluruhan data perusahaan Go Public yang sahamnya telah terdaftar dan diperdagangkan di Bursa Efek Indonesia sejak tahun 2007. Rentang waktu penelitian ini periode tahun 2007-2011 berdasarkan Indonesian capital Market Directory (ICMD) 2011. Jenis Industri yang digunakan yaitu semua kategori industri. Industri- industri tersebut telah mengeluarkan sustainability report periode 2007-2011.

\section{Variabel Penelitian}

1. Variabel Dependen

Varianel dependen merupakan variable yang dipengaruhi atau yang menjadi akibat karena adanya variabel independen. Variabel dependen dalam penelitian ini adalah Cummulative Abnormal Return (CAR) yang mengacu pada penelitian Sayekti dan Wondabio (2007). CAR merupakan penjumlahan abnormal return (AR) pada tanggal pengumuman laba selama periode pengamatan dari tahun 2007-2011. Dalam penelitian ini, peneliti menggunakan 11 hari periode pengamatan dimulai dari event date -5 sampai dengan event date +5 . Akan tetapi dikarenakan signifikansi model yang tidak bagus, maka penelitian ini dilakukan pada windows $4,+4$ (event date -4 sampai dengan event date +4) sebagai periode pengamatan karena menghasilkan model yang signifikansinya lebih baik dari event date yang ada. Pengukuran abnormal return dalam penelitian ini menggunakan marketadjusted model yang mengasumsikan bahwa pengukuran expected return saham perusahaan yang terbaik adalah return indeks pasar. Rumus untuk menghitung abnormal return sebagai berikut:

Berikut adalah rumus untuk menghitung abnormal return:

$$
\begin{aligned}
R_{i t} & =\frac{P_{i t}-P_{i t-1}}{P_{i t}-1} \\
R_{m t} & =\frac{I H S G_{t}-I H S G_{t-1}}{I H S G_{t-1}} \\
A R_{i t} & =R_{i t}-R_{m t}
\end{aligned}
$$

Keterangan:

Arit :Abnormal Return untuk perusahaan i pada hari ke-t.

Rit : Return harian perusahaan i pada hari ke-t.

Rmt : Return indeks pasar pada hari ke-t.

Pit :Harga saham perusahaan i pada waktu t. 
Pit-1 :Harga saham perusahaan i pada waktu t-1.

IHSGt:Indeks Harga Saham Gabungan pada waktu t.

IHSGt-1:Indeks Harga Saham Gabungan pada waktu t-1.

Selanjutnya perhitungan CAR untuk masing-masing perusahaan merupakan kumulasi abnormal return dari masingmasing perusahaan tersebut selama periode 2007-2011.

$$
C A R_{i,[t-4, t-4]}=\sum_{t=-4}^{i m-4} A R_{i t}
$$

Keterangan :

$$
C A R_{i,[t-4, t+4]} \text { :cumulative abnormal }
$$

return perusahaan i pada perusahaan ke$\mathrm{t}$ dan $(\mathrm{t}-4, \mathrm{t}+4)$ adalah lama periode pengamatan

$A R_{i, t}$

:abnormal return untuk perusahaan i pada hari ke-t.

Variabel Unexpected Earnings (UE) dihitung sebagai perubahan dari laba per saham perusahaan sebelum pos luar biasa tahun sekarang dikurangi dengan laba per saham perusahaan sebelum pos luar biasa tahun sebelumnya, dan di skalakan dengan harga per lembar saham pada akhir periode sebelumnya, dengan asumsi random walk.

$$
U E=\frac{E_{t}-E_{t-1}}{E_{t-1}}
$$

UE:Unexpected Earnings untuk perusahaan i pada waktu t.

Et: Laba per saham perusahaan (EPS) tahun yang bersangkutan.

Et-1: Laba per saham perusahaan (EPS) sebelum pada akhir periode sebelumnya.

Jadi cara pengukuran untuk memperoleh koefisien respon laba (ERC) menurut Cho dan Jung (1991) dalam Widiastuti (2002) adalah dengan slope koefisien dalam regresi abnormal return saham dan unexpected earnings (UE).

2. Variabel Independen

Variabel independen merupakan variabel yang mempengaruhi timbulnya perubahan variabel independen. Variabel Independen untuk mengukur CSR disclosure digunakan CSR index yang merupakan luas pengungkapan relatif setiap perusahaan sampel atas pengungkapan sosial yang dilakukannya dimana instrumen pengukur-an yang akan digunakan dalam penelitian ini mengacu pada Global Reporting Initiative (GRI), yang mengelompokkan informasi CSR ke dalam enam kategori yakni: ekonomi, lingkungan, tenaga kerja, hak asasi manusia, komunitas, dan produk . Dengan tema pengungkapan tanggung jawab sosial yang dipergunakan adalah tema pengungkapan yang terdapat pada Sustainability Reporting Guideliness 2006 yang dikeluarkan oleh Global Reporting Initiative (GRI).

Skor pengungkapan tanggung jawab sosial akan dihitung dengan menggunakan content analysis yaitu metode penelitian yang menggunakan seperangkat prosedur untuk membuat pendugaan (inference) atas suatu teks. Dari hasil penelusuran ini akan dipetakan pengungkapan sosial yang dilakukan oleh perusahaan. Setelah Sustainability Report ditelusuri berdasar-kan tema, maka peneliti akan melakukan pemetaan dengan menghitung banyaknya perusahaan yang melakukan pengungkapan sosial berdasarkan tema yang ada.

Penilaian dilakukan sesuai dengan metode scoring bobot berbeda. Metode scoring ini memberikan bobot yang berbeda untuk setiap item pengungkapan yang sesuai dengan compliance yang terdapat dalam GRI. Hal ini dilakukan supaya bobot maksimal yang diberikan bisa mencerminkan nilai pengungkapan yang sebenarnya. Untuk menghitung besarnya skor pengungkapan masing-masing perusahaan, digunakan rumus sebagai berikut 


$$
\begin{gathered}
\text { ESCORE }_{\mathrm{it}}=\Sigma \frac{\text { SkorAktual }}{\text { TotalMaksimalSkor }} \times \text { BobotPerIndikator } \\
=\left(\frac{\text { SkoraktualEC }}{\text { TotalMaksimalSkor }}\right) \times \text { BobotEC }+\left(\frac{\text { SkoraktualEN }}{\text { TotalMaksimalSkor }}\right) \times \text { BobotEN }+ \\
\left(\frac{\text { SkoraktualLA }}{\text { TotalMaksimalSkor }}\right) \times \text { BobotLA }+\left(\frac{\text { SkoraktualHR }}{\text { TotalMaksimalSkor }}\right) \times \text { BobotHR }+ \\
\left(\frac{\text { SkoraktualSO }}{\text { TotalMaksimalSkor }}\right) \times \text { BobotSO }+\left(\frac{\text { SkoraktualPR }}{\text { TotalMaksimalSkor }}\right) \times B o b o t P R .
\end{gathered}
$$

Keterangan: ESCOREit : Indeks CSR disclosure per emiten/perusahaan sampel i pada periode t.

3. Variabel Kontrol

Meskipun ada beberapa variabel yang diprediksi dapat mempengaruhi respon pasar terhadap laba, tetapi penelitian ini hanya menggunakan dua variabel kontrol, yaitu struktur permodalaan perusahaan (dengan diproksi dengan leverage) dan informativeness of earnings (yang diproksi dengan ukuran perusahaan atau size).

a. Leverage

Rasio leverage merupakan rasio hutang yang digunakan sebagai variabel kontol dalam penelitian ini, dengan rumus sebagai berikut:

Debt to Equity Ratio $(\mathrm{DER})=$

$$
\frac{\text { TotalDebt }}{\text { StockholdresEquity }} \times 100 \%
$$

b. Ukuran perusahaan (Size)

Ukuran perusahaan (Size) dihitung dengan Logaritma Total Asset.

\section{Teknik Analisis Data}

\section{Uji Kesamaan Koefisien}

Model I (tanpa variabel kontrol):

CARi $=\alpha 0+\beta 1$ ESCOREit $+\beta 2$ UEit $+\beta 3$ ESCOREit*UEit $+\varepsilon i t$

Model II (dengan variabel kontrol):

CARi $=\alpha 0+\beta 4$ ESCOREit $+\beta 5$ UEit $+\beta 6$ LEVERAGEit $+\beta 7$ SIZEit $+\beta 8$

ESCOREit*UEit $+\varepsilon i t$
Karena penelitian ini menggunakan data selama lima tahun (2007-2011) dimana terdapat data time series ditandai dengan lebih dari satu periode waktu penelitan dan cross section untuk semua industri pada satu tahun maka menggunakan uji kesamaan koefisien/pooling untuk mengetahui apakah pooling data (penggabungan data cross sectional dengan time series) dapat dilakukan, maka perlu dilakukan uji kesamaan koefisien (comparing two regression). Pengujian ini dilakukan untuk mengetahui apakah ada perbedaan intercept, slope, atau keduanya diantara persamaan regresi yang ada. Bila terbukti ada perbedaan, maka data penelitian tidak dapat di-pool, namun harus diteliti secara cross-sectional. Uji kesamaan koefesien menggunakan variabel dummy dengan aplikasi Eviews 7. Langkah-langkah pengujiannya adalah sebagai berikut:

a. Pilih dan masukkan model regresi yang kedalam program Eviews. Kemudian masukan model regresi tersebut kedalam estimate equation. Model regresi yang digunakan adalah: akan dilakukan uji kesamaaan koefisien 
Keterangan:

CARi : Cumulative abnormal return perusahaan i pada perusahaan ke-t dan $(\mathrm{t}-4, \mathrm{t}+4)$ adalah lama periode pengamatan

ESCOREit: Indeks CSR disclosure per emiten/ perusahaan sampel i pada periode $\mathrm{t}$

UEit : Unexpected earnings perusahaan i pada periode t.

ESCOREit*UEit: Interaksi dari variabel antara ESCORE dan UE.

LEVERAGEit : Rasio hutang yang dihitung dengan Debt to Equity Ratio.

SIZEit : Rasio yag digunakan untuk mengukur perusahaan dengan Logaritma Total

Asset.

$\beta 1 \ldots \beta 8 \quad$ : Koefisien regresi.

$\varepsilon \_$it $\quad$ : error term.

b. Pada output estimate equation pilih menu view, kemudian dilanjutkan pilih stability test chow breakpoint test. Masukan breakpoint dates dengan angka sampel +1 , dari tahun pertama sampel sampai dengan tahun kedua sampel. Dimana tahun penelitian yang digunakan dalam penelitian ini adalah 5 tahun dengan jumlah sampel 7 perusahaan per tahun. Jadi, angka breakpoint dates-nya adalah 8152229 .

c. Kriteria pengambilan keputusan:

(1) Bila Prob. $F<0,05$ maka pooling tidak dapat dilakukan.

(2) Bila Prob. $F \geq 0,05$ maka pooling dapat dilakukan.

d. Jika ternyata diketahui bahwa tidak dapat dilakukan pooling maka perhitungan akan dilakukan per tahun (cross sectional) yaitu masing-masing untuk tahun 2007, 2008, 2009, 2010, dan 2011.

2. Uji Keberartian Model (Uji F)

Uji ini dilakukan dengan memakai uji $\mathrm{F}$ yang pada dasarnya menunjukkan apakah model regresi dapat digunakan atau tidak untuk menguji hipotesis serta apakah semua variabel independen atau bebas yang dimasukkan dalam model mempunyai pengaruh secara bersamasama terhadap variabel dependen. Langkah-langkahnya adalah sebagai berikut:
(1). Menentukan hipotesis.

Model I:

H01 : $\beta 1=\beta 2=\beta 3=0$ (Model regresi linear ganda tidak signifikan atau tidak ada pengaruh antara variabel independen dan variabel interaksi terhadap variabel dependen).

Ha1: Paling tidak ada satu $\beta \mathrm{j} \neq 0$ (Model regresi linear ganda signifikan atau ada pengaruh antara variabel independen, variabel interaksi terhadap variabel dependen).

Model II:

H02: $\beta 4=\beta 5=\beta 6=\beta 7=\beta 8=0$ (Model regresi linear ganda tidak signifikan atau tidak ada pengaruh antara variabel independen, variabel kontol dan interaksi terhadap variabel dependen).

Ha2: Paling tidak ada satu $\beta \mathrm{j} \neq 0$ (Model regresi linear ganda signifikan atau ada pengaruh antara variabel independen, variabel kontrol dan interaksi terhadap variabel dependen).

(2). Kriteria pengambilan keputusan diambil dengan membandingkan nilai Sig-F dengan $\alpha(0,05)$, yaitu:

a. Jika Sig-F $<\alpha(0,05)$ maka tolak Ho artinya model regresi signifikan, artinya secara simultan semua variabel independen dan kontrol 
berpengaruh terhadap variabel dependen.

b. Jika Sig-F $\geq \alpha(0,05)$ maka tidak tolak Ho artinya model regresi tidak signifikan, artinya secara simultan semua variabel independen dan kontrol tidak berpengaruh terhadap variabel dependen.

1). Uji t

Uji ini dilakukan dengan memakai uji $t$ untuk mengetahui apakah masing-masing variabel independen berpengaruh terhadap variabel dependen (Gujarati, 2009 : 249). Langkah-langkah pengujiannya adalah sebagai berikut:

(1). Menentukan hipotesis

Model 1:

a. Ho : $\beta 3=0$

b. $\mathrm{Ha}: \beta 3<0$

Model 2:

a. Ho : $\beta 8=0$

b. Ha : $\beta 8<0$

(2). Menentukan taraf signifikansi ( $\alpha$ ) yaitu 0,05 . Kriteria pengambilan keputusan yaitu:

(a). Uji 1 sisi

1). Jika Sig-t $<0,05$ dan arah penelitian sesuai hipotesis maka tolak Ho. Artinya adalah variabel independen cukup bukti berpengaruh sesuai arah hipotesis terhadap variabel dependen.

2). Jika Sig-t $\geq 0,05$ dan arah penelitian tidak sesuai hipotesis maka tidak tolak Ho. Artinya adalah variabel independen tidak cukup bukti berpengaruh sesuai arah hipotesis terhadap variabel dependen.

(b). Uji 2 sisi

1). Jika Sig-t < 0,05 maka tolak Ho. Artinya adalah variabel independen cukup bukti berpengaruh terhadap variabel dependen.

2). Jika Sig-t $\geq 0,05$ maka tidak tolak Ho. Artinya adalah variabel independen tidak cukup bukti berpengaruh terhadap variabel dependen.

\section{Koefisien Determinansi (R2)}

(1). Nilai koefisien determinansi merupakan suatu ukuran yang menunjukkan proporsi (bagian) atau persentase total variasi dalam variabel dependen yang dijelaskan oleh model. Dua sifat Koefisien Determinasi (R2) yaitu:

(2). Nilai R2 selalu positif, karena merupakan rasio dari jumlah kuadrat.

Batasnya adalah $0<\mathrm{R} 2<1$, dimana:

a). Jika R2 = 0 , berarti variabel independen tidak mampu menjelaskan variabel dependen,atau model regresi tidak tepat meramalkan Y.

b). Jika $\mathrm{R} 2=1$, berarti model regresi dapat meramalkan Y secara sempurna.

Kelemahan mendasar penggunaan koefisien determinasi adalah bias terhadap jumlah variabel independen yang dimasukkan ke dalam model. Setiap tambahan satu variabel independen, maka R2 pasti meningkat tidak perduli apakah variabel tersebut berpengaruh secara signifikan terhadap variabel dependen. Oleh karena itu banyak peneliti menganjurkan untuk menggunakan nilai Adjusted R2 pada saat mengevaluasi mana model regresi terbaik. Tidak seperti R2, nilai Adjusted R2 dapat naik atau turun apabila satu variabel independen ditambahkan kedalam model (Ghozali 2008). 


\section{ANALISIS DAN HASIL PENELITIAN}

Analisis Data

1. Statistik Deskriptif

a. Cumulative Abnormal Return (CAR)

Tabel 1

Cumulative Abnormal Return (CAR)

vescriptve Satıstucs

\begin{tabular}{|c|c|c|c|c|c|}
\hline & $N$ & Wirinun & Naxim_.n & Mean & St-1. Dev aticn \\
\hline SAR4 & 35 & -.09 & .17 & $00 \subseteq 2$ & .06013 \\
\hline Valid $\vee$ (I s.svist; & 35 & & & & \\
\hline
\end{tabular}

Sumber: Output SPSS 20.0

Tabel 1. Cumulative abnormal return (CAR) hasil yang diperoleh dari penjumlahan return tidak normal (abnormal return) pada tanggal pengumuman laba selama 11 hari periode pengamatan, dimulai dari event date -5 sampai dengan event date +5 . Dan yang terpilih adalah CAR $(-4,+4)$ sebagai CAR yang memiliki output terbaik. Dari hasil pengolahan data, ternyata cumulative abnormal return terkecil adalah sebesar -0.09 yang dimiliki oleh PT Bukit Asam (Persero) Tbk tahun 2008 dan PT Holcim Indonesia Tbk pada tahun 2007. Sedangkan cumulative abnormal return terbesar adalah sebesar 0.17 yang dimiliki oleh PT Holcim Indonesia Tbk pada tahun 2007. Rata-rata cumulative abnormal return adalah sebesar 0.0092 dengan standar deviasi sebesar 0.06013 .

b. Pengungkapan Tanggung Jawab Sosial (CSR disclosure)

Tabel 2.

Pengungkapan CSR Descriptive Statistics

\begin{tabular}{|l|r|r|r|r|r|}
\hline & $\mathrm{N}$ & $\begin{array}{c}\text { Minimu } \\
\mathrm{m}\end{array}$ & $\begin{array}{c}\text { Maximu } \\
\mathrm{m}\end{array}$ & Mean & $\begin{array}{c}\text { Std. } \\
\text { Deviation }\end{array}$ \\
\hline ESCORE & 35 &, 17 & 25,07 & 9,2617 & 7,35307 \\
$\begin{array}{l}\text { Valid N } \\
\text { (listwise) }\end{array}$ & 35 & & & & \\
\hline
\end{tabular}

Sumber: Output SPSS 20.0

Tabel 2 Pengungkapan CSR Descriptive Statisticss dengan penjelasannya Escore diperoleh dari bobot skoring, dengan cara total skor aktual per kategori perusahaan dibagi dengan total skor kategori maksimum lalu dikali dengan skor maksimum per kategori. Escore tiap perusahaan per kategori lalu dijumlahkan untuk mengetahui tingkat pengungkapan informasi pada laporan tahunan. ESCORE maksimum yang diperoleh sebesar 25.07 dimiliki oleh PT Aneka Tambang (Persero) Tbk pada tahun
2009. Sedangkan ESCORE minimum dengan nilai sebesar 0.17 dimiliki oleh PT Pembangunan Jaya Ancol, Tbk pada tahun 2007. Hasil Escore maksimum yang dimiliki hanya mencapi $25.07 \%$, tidak sampai $50 \%$ dari total pengungkapan seluruhnya. Hal ini membuktikan masih sangat rendah kesadaran perusahaan di Indonesia untuk mengungkapkan kinerja sosialnya. Rata-rata ESCORE adalah sebesar 9.2617 dengan standar deviasi sebesar 7.35307 .

Uji Kesamaan Koefisien 
Dengan pooling yang dilakukan di Eviews 7, diperoleh output sebagai berikut:

Tabel 3

Hasil Pooling Model I Periode 2007-2011

Chow Breakpoint Test: 8152229

Null Hypothesis: No breaks at specified breakpoints

Varying regressors: All equation variables

Equation Sample: 135

\begin{tabular}{llll}
\hline \hline F-statistic & 0.588195 & Prob. F(16,15) & 0.8485 \\
Log likelihood ratio & 17.04460 & Prob. Chi-Square(16) & 0.3827 \\
Wald Statistic & 9.411117 & Prob. Chi-Square(16) & 0.8955 \\
\hline \hline
\end{tabular}

Sumber: Output Eviews 7

Kriteria pengambilan keputusan sebagai berikut:

a. Bila Prob.F $<0.05$ maka pooling tidak dapat dilakukan.

b. Bila Prob.F $\geq 0.05$ maka pooling dapat dilakukan. c. Dari hasil pooling model I pada tabel 3, untuk memutuskan kriteria pengambilan keputusan dapat dilihat melalui nilai Prob. F $(16,15)$ di atas sebesar 0.08485. Angka tersebut $\geq 0.05$ sehingga dapat disimpulkan bahwa pooling dapat dilakukan.

Tabel 4

Hasil Pooling Model II Periode 2007-2011

Chow Breakpoint Test: 8152229

Null Hypothesis: No breaks at specified breakpoints

Varying regressors: All equation variables

Equation Sample: 135

\begin{tabular}{llll}
\hline \hline F-statistic & 3.268601 & Prob. F(24,5) & 0.0955 \\
Log likelihood ratio & 98.51684 & Prob. Chi-Square(24) & 0.0000 \\
Wald Statistic & 78.44642 & Prob. Chi-Square(24) & 0.0000 \\
\hline \hline
\end{tabular}

Sumber: Output Eviews 7

Dari hasil pooling model 2 pada tabel 4, untuk memutuskan kriteria pengambilan keputusan dapat dilihat melalui nilai Prob. F $(24,5)$ di atas sebesar 0.0955. Angka tersebut $\geq 0.05$ sehingga dapat disimpulkan bahwa pooling dapat dilakukan. 
Tabel 5

Hasil Uji F Model I

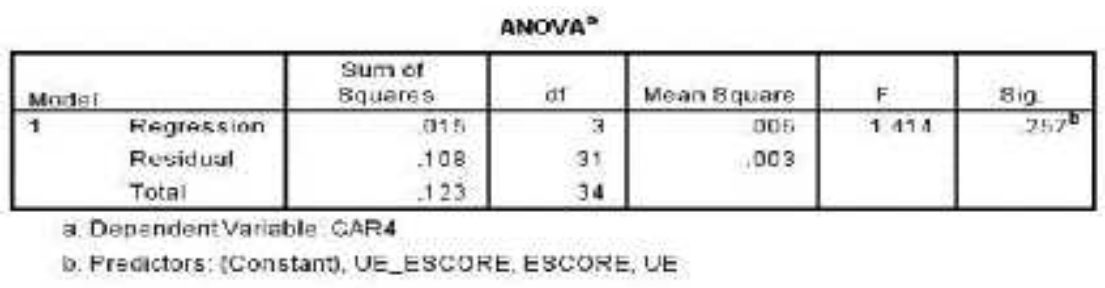

Kriteria pengambilan keputusan diambil dengan membandingkan nilai Sig-F dengan $\alpha$ $(0,05)$, yaitu:

a. Jika Sig-F $<\alpha(0,05)$ maka tolak Ho artinya model regresi signifikan, artinya secara simultan semua variabel independen dan kontrol berpengaruh terhadap variabel dependen.

b. Jika Sig-F $\geq \alpha(0,05)$ maka tidak tolak Ho artinya model regresi tidak signifikan, artinya secara simultan semua variabel independen dan kontrol tidak berpengaruh terhadap variabel dependen.

Pada tabel 5 di atas, untuk Uji F Model I didapat nilai probabilitas $\mathrm{F}_{\text {statistik }}$ sebesar 0.257, Sig-F $>\alpha(0,05)$ maka tidak tolak $\mathrm{H}_{01}$ artinya model regresi di Model I tanpa variabel kontrol tidak signifikan, artinya variabel independen tidak berpengaruh terhadap variabel dependen. Jadi, variabel independen (ESCORE) bukan merupakan variabel penjelas untuk variasi variabel dependen (cumulative abnormal return).

Tabel 6

Hasil Uji F Model II

ANONA ${ }^{2}$

\begin{tabular}{|c|c|c|c|c|c|c|}
\hline & & $\begin{array}{l}\text { Sum of } \\
\text { squares }\end{array}$ & df & Mean Square & $F$ & Sig. \\
\hline \multirow[t]{3}{*}{1} & Regression & .050 & 5 & .010 & 3.953 & $.007^{5}$ \\
\hline & Residual & 073 & 29 & 003 & & \\
\hline & Total & .123 & 34 & & & \\
\hline
\end{tabular}

a. Dependent Variable: CAR4

b. Predictors; (ConstanD, UE_ESCORE, SZE, LEVERAGE, ESCORE, UE

Pada tabel 6 di atas, untuk Uji F Model II didapat nilai probabilitas $\mathrm{F}_{\text {statistik }}$ sebesar 0.007 , Sig-F $<\alpha(0,05)$ maka tolak $\mathrm{H}_{02}$ artinya model regresi di Model II dengan signifikan, artinya secara simultan variabel independen (ESCORE), dan variabel kontrol (LEVERAGE dan SIZE), berpengaruh terhadap variabel dependen (cumulative abnormal return ). Jadi, semua variabel independen dan variabel kontrol, secara simultan merupakan variabel penjelas yang signifikan terhadap cumulative abnormal return (variabel dependen). 
Uji Koefisien Regresi Parsial

Tabel 7

Hasil Uji T Model I

Coefficients $^{3}$

\begin{tabular}{|c|c|c|c|c|c|c|}
\hline \multirow[b]{2}{*}{ Mod } & & \multicolumn{2}{|c|}{ Unstandardized Coefficients } & \multirow{2}{*}{$\begin{array}{c}\text { Standardized } \\
\text { coeficients } \\
\text { Beta }\end{array}$} & \multirow[b]{2}{*}{$t$} & \multirow[b]{2}{*}{ Sig. } \\
\hline & & $B$ & Std. Error & & & \\
\hline \multirow[t]{4}{*}{1} & (Constant) & .037 & .017 & & 2.145 & .040 \\
\hline & ESCORE & .002 & .001 &.,- 304 & -1.680 & .103 \\
\hline & UE &,- 052 & .038 & -.650 & -1.352 & .186 \\
\hline & UE_ESCORE & .003 & .002 & .637 & 1.293 & .206 \\
\hline
\end{tabular}

a. Dependent Variable: GAR4

Karena alat uji yang digunakan dalam penelitian ini adalah alat uji regresi berganda dengan model interaksi, maka variabel individual dalam persamaan regresi tidak diinterpretasikan. Interprestasi hanya dilakukan terhadap interaksi antar variabel. Untuk melihat pengaruh pengungkapan CSR ditentukan dengan melihat arah koefisien variabel interaksi ESCORE*UE.

Nilai probabilitas Sig-t untuk model I pada tabel 7 untuk ESCORE*UE adalah 0.206. Uji koefisien regresi secara terpisah ditunjukkan melalui uji t. Uji t terhadap interaksi variabel unexpected earnings dan pengungkapan CSR (ESCORE*UE) terhadap CAR4 menghasilkan koefisien regresi sebesar 0.003 . Nilai probabilitasnya adalah $0.206 \geq \alpha=0.05$, maka tidak tolak Ho. Dengan demikian tidak terdapat cukup bukti bahwa ESCORE berpengaruh negatif terhadap ERC.

a. Koefisien Determinasi (Goodness of Test)

\section{Tabel 8}

Hasil $\mathbf{R}^{2}$ Model I

Model Summary

\begin{tabular}{|l|r|r|r|r|}
\hline Model & $R$ & R Square & $\begin{array}{c}\text { Adjusted } R \\
\text { Square }\end{array}$ & $\begin{array}{c}\text { Std. Error of } \\
\text { the Estimale }\end{array}$ \\
\hline 1 & $.347^{2}$ & 120 & .035 & .05906 \\
\hline
\end{tabular}

a. Predictors: (Constant), UE_ESCORE, ESCORE, UE

Angka R2 (koefisien determinasi) sebesar 0,120 pada tabel 8 menunjukkan bahwa $12 \%$ variasi cumulative abnormal return (CAR) dapat dijelaskan oleh satu variabel independen, yaitu ESCOREit 
Tabel 9

Hasil $\mathbf{R}^{2}$ Model II

Model Summary

\begin{tabular}{l|r|r|r|c|}
\hline Madel & R & R Square & $\begin{array}{c}\text { Adjusted R } \\
\text { Square }\end{array}$ & $\begin{array}{c}\text { Std. Error of } \\
\text { the Estimate }\end{array}$ \\
\hline 1 & $.637^{3}$ & 405 & .303 & .05021 \\
\hline
\end{tabular}
a Predictors: (Constanf), UE_ESCORE, SIZE, LEVERAGE,
ESCORE, UE

Angka R2 (koefisien determinasi) sebesar 0,405 pada tabel 9 menunjukkan bahwa $40,5 \%$ variasi cumulative abnormal return (CAR) dapat dijelaskan oleh variasi satu variabel independen dan dua kontrol, yaitu LEVERAGEit, SIZEit, dan ESCOREit.

\section{Uji Asumsi Klasik}

a. Multikolineritas. Uji Multikolineritas menggunakan variance inflation factor (VIF) dan tolerance, pada kolom Collinearity Statistics semua variabel bebas (ESCORE, UE, LEVERAGE, SIZE, dan ESCORE*UE) Tolerance $\geq$ 0,1 dan VIF $<10$ sehingga tolak H02 yang artinya tidak terjadi multikolinearitas dalam model II.

b. Heterokedastisitas. Pengujian ini dilakukan dengan menggunakan Uji Park yang dihasilkan melalui SPSS 20.0. Model regresi yang baik tidak terjadi heteroskedastisitas. Dasar Pengambilan Keputusan: tidak terjadi heteroskedastisitas, Apabila nilai signifikansi (Sig.) > 0,05. Terjadi heteroskedastisitas, Apabila nilai signifikansi (Sig.) < 0,05. Hasil menunjukkan variable UE, Escore,dan UE*Escore memiliki nilai signifikasi $0.942 ; \quad 0.916 ; \quad 0.883 \quad$ yang kesemuannya di atas 0,05 . Berarti tidak terdapat heteroskedastisitas dalam model I.Hasil menunjukkan variable UE, Escore, Leverage, Size, UE*Escore memiliki nilai signifikasi $0.879 ; 0.887 ; 0.616 ; 0.106 ; 0.187$ yang kesemuannya di atas 0,05. Berarti tidak terdapat heteroskedastisitas dalam model II.

c. Autokorelasi. Adapun kriterianya dalam uji LM test, Jika Sig-t Res_2 z 0,05 berarti tolak Ho, dan apabila Sig-t Res_2 $<0,05$ berarti tidak tolak Ho. Pada variabel res_2 model I diketahui signifikansi 0.18 dibandingkan dengan Sig-t Res_2 $\geq 0,05$ berarti tolak H01. Artinya tidak terdapat autokorelasi pada model I. Pada variabel res_4 model II diketahui signifikansi 0.342 dibandingkan dengan Sig-t Res_4 $\geq$ 0,05 berarti tolak H01. Artinya tidak terdapat autokorelasi pada model II.

d. Normalitas. Pengujian normalitas menggunakan Kolmogorov-Smirnov pada SPSS 20.0, dengan hasil dan kriterianya sebagai berikut: Jika Sig-t $\geq$ 0,05 berarti tidak tolak Ho. Artinya residu data berdistribusi normal. Jika Sig-t $<0,05$ berarti tolak Ho. Artinya residu data tidak berdistribusi normal. Pada hasil mengatakan Asymp. Sig. (2tailed) sebesar 0.475 berarti Sig-t $\geq$ 0,05 berarti tidak tolak H02. Artinya residu data Model I berdistribusi normal. Hasil untuk model II, Asymp. Sig. (2-tailed) sebesar 0.949 berarti Sig-t $\geq 0,05$ berarti tidak tolak H02. Artinya residu data Model II berdistribusi normal. 


\section{Hasil Penelitian}

Tabel 10

Hasil Uji Penelitian

\begin{tabular}{|c|c|c|}
\hline $\begin{array}{c}\text { Variabel Dependen: } \\
\text { CAR }_{4}\end{array}$ & $\begin{array}{c}\text { Model I } \\
\text { (Tanpa kontol) }\end{array}$ & $\begin{array}{c}\text { Model II } \\
\text { (Variabel kontol) }\end{array}$ \\
\hline & $\begin{array}{c}\text { Koef. } \\
\text { (p-value) }\end{array}$ & $\begin{array}{c}\text { Koef. } \\
\text { (p-value) }\end{array}$ \\
\hline Constanta & +0.037 & +0.264 \\
\hline $\mathrm{ESCORE}_{\mathrm{it}}$ & - 0.002 & - 0.002 \\
\hline $\mathrm{UE}_{\mathrm{it}}$ & - 0.052 & - $\quad 0.021$ \\
\hline LEVERAGE $_{\text {it }}$ & & +0.58 \\
\hline SIZE $_{i t}$ & & - 0.017 \\
\hline \multirow[t]{2}{*}{$\mathrm{ESCORE}_{\mathrm{it}} * \mathrm{UE}_{\mathrm{it}}$} & +0.003 & +0.001 \\
\hline & $(0.206)$ & $(0.467)$ \\
\hline $\mathrm{R}^{2}$ & 0.120 & 0.405 \\
\hline Adj. $R^{2}$ & 0.035 & 0.303 \\
\hline $\mathrm{F}$ & 0.257 & 0.007 \\
\hline LM-Test & 0.018 & 0.342 \\
\hline
\end{tabular}

\section{Keterangan: $\alpha=\mathbf{5 \%}$}

Pada tabel 10 di atas menyajikan dua model regresi berganda, yaitu Model I tanpa variabel kontrol dan Model II dengan memasukkan variabel kontrol. Uji $\mathrm{F}$ untuk model I menunjukkan hasil yang tidak signifikan (sig 0.257), dan model II memiliki nilai uji $\mathrm{F}$ yang signifikan (sig 0.007). Dari hasil tersebut dapat diketahui bahwa model I untuk ESCORE bukan merupakan variabel penjelas yang signifikan terhadap CAR. Sedangkan hasil uji F model II menunjukkan hasil yang lebih baik dibandingkan dengan hasil uji model I tanpa menyertakan variabel kontrol. Hal ini terbukti bahwa model II dapat menjelaskan variasi dari variabel dependen, yaitu CAR.
Hasil pengujian regresi menunjukkan bahwa model I memiliki adjusted R2 sebesar 0.035, sedangkan model II memiliki adjusted R2 yang lebih baik, yaitu 0.303 . Hal ini sesuai dengan penelitian terdahulu, bahwa respon pasar terhadap laba dipengaruhi oleh beberapa faktor, yaitu struktur permodalan perusahaan dan informativeness of earnings (yang dalam penelitian ini masing-masing diproksi dengan variabel leverage dan size). Peningkatan R2 tersebut menunjukkan bahwa pengikutsertaan variabel kontrol meningkatkan explainability model atau explainability variabel independen terhadap perilaku variabel dependen (CAR).

Dalam hasil uji sig-t pada model I dan II, tampak bahwa variabel interaksi ESCOREit*UEit tidak signifikan pada tingkat 
5\% (nilai probabilitas model I sebesar 0.206 dan model II sebesar 0.467), tetapi tanda koefisien positif, yang tidak sesuai dengan hipotesis penelitian (koefisien regresi model I 0.003 dan model II 0.001). Hasil pengujian model ini tidak dapat mendukung hipotesa yang diajukan dalam penelitian ini, yaitu bahwa pengungkapan CSR berpengaruh negatif terhadap Koefisien Respon Laba. Menurut hipotesis yang diajukan bahwa pengungkapan informasi CSR (CSR disclosure) dalam laporan tahunan akan menurunkan koefisien respon laba.

\section{Pembahasan}

Pengaruh tanggung jawab sosial terhadap koefisien respon laba berpengaruh negatif seharusnya sesuai dengan premis bahwa informativeness of earnings akan semakin besar ketika terdapat ketidakpastian mengenai prospek perusahaan di masa datang (Widiastuti, 2002). Diharapkan jika perusahaan melakukan pengungkapan tanggung jawab sosial dalam laporan tahunannya akan dapat mengurangi ketidakpastian tersebut. Dengan demikian pengungkapan tanggung jawab sosial tersebut akan menurunkan koefisien respon laba.

Jadi, berdasarkan pengujian di atas, hipotesis yang diajukan dalam penelitian ini yang menyatakan bahwa pengungkapan tanggung jawab sosial dalam laporan tahunan perusahaan berpengaruh negatif terhadap koefisien respon laba tidak didukung oleh data empiris dari sampel penelitian ini yang menyatakan tidak terbukti bahwa pengaruh tanggung jawab sosial berpengaruh negatif terhadap koefisien respon laba. Dengan perincian hasil penelitian untuk model I dan II konsisten dengan hasil temuan Widiastuti (2002) pada model I dan II yang menguji pengaruh luas pengungkapan sukarela terhadap koefisien respon laba. Widiastuti (2002) juga menemukan pengaruh pengungkapan sukarela yang positif dan signifikan pada level 10\% terhadap ERC.
Sedangkan menurut temuan Sayekti dan Wondabio (2007) yang menggunakan variabel kontrol dalam penelitiannya. Pada model I tanpa memasukan variabel kontrol memberikan hasil yang sejalan dengan model I peneliti, yaitu berpengaruh positif dan signifikan. Untuk hasil penelitian model II Sayekti dan Wondabio (2007) tidak sesuai dengan temuan peneliti yang berpengaruh positif tidak signifikan. Berdasarkan uji empiris Sayekti dan Wondabio (2007) menghasilkan pengaruh yang negatif dan signifikan pada model II.

Secara keseluruhan penelitian ini tidak berhasil menunjukkan hasil yang konsisten tentang pengaruh pengungkapan CSR terhadap koefisien respon laba. Hasil analisis regresi dengan menggunakan model I maupun model II menunjukkan bahwa tidak terdapat cukup bukti pengaruh CSR berpengaruh negatif terhadap koefisien respon laba. Berdasarkan hasil tersebut penelitian ini tidak berhasil menolak hipotesis nol.

Terdapat beberapa penjelasan terhadap hasil tersebut. Pertama, sampel yang diuji dalam penelitian terlalu sedikit, sebanyak 7 perusahaan yang disebabkan oleh ketatnya penyeleksian sampel berdasarkan sustainability report. Kedua, Indikator pengungkapan CSR dalam sustainability report perusahaan tidak semuanya diungkapkan. Ketiga, pengujian dilakukan dengan menggunakan semua jenis industri yang terdaftar di BEI periode 2007-2011, sehingga menghasilkan data yang timpang atau tidak sesuai antar tiap perusahaan. Keempat, ada efek yang berarti dalam penambahan variabel kontrol di model II. Karena adanya perbedaan hasil adjusted R2 yang lebih baik dari model I yang tanpa variabel kontrol (0.120) dan model II dengan variabel kontrol (0.405). Tetapi dalam hasil ESCOREit*UEit nilai uji $\mathrm{t}$ pada model $\mathrm{I}$ (0.003) dan model II (0.001) memberikan hasil yang tidak merubah model II sesuai dengan hipotesis yang diajukan. 


\section{Simpulan Dan Saran}

Berdasarkan hasil penelitian, maka jawaban atas batasan masalah yang diajukan adalah tidak terbukti menyatakan bahwa Pengungkapan Tanggung jawab sosial berpengaruh negatif terhadap koefisien respon laba.

Beberapa saran yang dapat diberikan oleh peneliti sehubungan dengan keterbatasan penelitian ini : Bagi investor sebaiknya tidak menilai kualitas laba hanya berdasarkan laporan CSR saja karena tidak berpengaruh signifikan; bagi perusahaan walaupun dalam hasil penelitian ini pengungkapan laporan CSR tidak berpengaruh, tetapi laporan CSR sekarang sudah menjadi kewajiban yang harus diungkapkan; bagi peneliti selanjutnya menambah variabel lain untuk variabel independen dengan pengaruh dari karakteristik perusahaan (contoh: growth, peristensi laba, beta, likuiditas, profitabiltas), variabel intervening (kinerja lingkungan), dan variabel moderating (kinerja lingkungan dengan PROPER) yang dapat mempengaruhi pengungkapan tanggung jawab sosial dan koefisien respon laba.

\section{DAFTAR PUSTAKA}

Andreas Lako. 2011. Dekonstruksi CSR \& Reformasi Paradigma Bisnis \& Akuntansi, Jakarta: Penerbit Erlangga.

Belkaoui, Ahmed Riahi. 2001. Teori Akuntansi, Buku 2, Edisi pertama, Jakarta: Salemba Empat.

Bursa Efek Jakarta. 2011. Indonesian Capital Market Directory, Institute For Economy and Financial Research.

Cooper, Donald R. dan Pamela S. Schindler . 2011. Business Research Methods, 11th Edition, New York: McGraw Hill.
Darwin, Ali. 2004. Penerapan Sustainability Reporting di Indonesia. Konvensi Nasional Akuntansi V, Program Profesi Lanjutan. Yogyakarta, 13-15 Desember.

Dergibson S. dan Sugiarto. 2006. Metode Statistika untuk Bisnis dan Ekonomi, Jakarta: Gramedia Pustaka Utama.

Etty Murwaningsari. 2009. Hubungan Corporate Governance, Corporate Social Responsibilities dan Corporate Financial Performance Dalam Satu Continuum, Jurnal Akuntansi Dan Keuangan, Vol. 11, No. 1, Mei 2009: 30-41.

Ikatan Akuntansi Indonesia. 2009b. Standar Akuntansi Keuangan, Penyajian Laporan Keuangan, Jakarta: Salemba Empat.

Ghozali, Imam. 2008. Aplikasi Analisis Multivariate dengan Program SPSS, Semarang: Badan Penerbit Universitas Diponogoro.

Gujarati, Damodar N. 2009. Basic Econometrics, Edisi 5, New York : McGraw Hill.

Jaswadi. 2004. Dampak Earning Reporting Lags terhadap Koefisien Respon Laba, Jurnal Riset Akuntansi Indonesia (JRAI), Vol.7, No.3.

Jogiyanto H.M. 2003. Teori Portofolio dan Analisis Investasi, Yogyakarta : BPFE-Yogyakarta.

Lang, M. and Lundholm, R. 1993. CrossSectional Determinants of Analyst Ratings of Corporate Disclosures. Journal of Accounting Research, 31 , 246-271. http://dx.doi.org/10.2307/2491273 
Lev, B. 1989. On the Usefulness of Earnings and Earnings Research-Lessons and Directions from Two Decades of Empirical Research. Journal of Accounting Research, 27, 153-192. http://dx.doi.org/10.2307/2491070

Mayangsari, Sekar. 2004. Bukti Empiris Pengaruh Spesialisasi Industri Auditor terhadap Earnings Response Coefficient. Jurnal Riset Akuntansi Indonesia (JRAI). Vol. 7 (2): 154-178.

Reni Retno Anggraini (2006), Pengungkapan Informasi Sosial dan Faktor-Faktor yang Mempengaruhi Pengungkapan Informasi Sosial dalam Laporan Keuangan Tahunan (Studi Empiris pada PerusahaanPerusahaan yang terdaftar Bursa Efek Jakarta), Disampaikan pada Simposium Nasional Akuntansi IX 23-26 Agustus di Padang.

Scott, William R. 2009. Financial Accounting Theory, 5th Edition, Toronto, Ontario : Pearson Canada Inc.

Simms, Jane.2002. "Business: Corporate Social Responsibility." London, November, Volume 130 (1311), p, 1

Sutopoyudo. 2009. Pengaruh Penerapan Corporate Social Responsibility (CSR) terhadap Profitabilitas Perusahaan. Sutopoyudo's Weblog at http://www.wordpress.com. Diakses tanggal 5 Desember 2013
Suwardjono. 2008. Teori Akuntansi, Yogyakarta : BPFE-Yogyakarta.

Yosefa Sayekti dan Ludovicus Sensi Wondabio. 2007. Pengaruh CSR Disclosure Terhadap Earning Response Coeficient, disampaikan pada Simposium Nasional Akuntansi X 26-28 Juli di Unhass Makasar (26-28 Juli).

Yuliana, Sidhi dan Sukoharsono. 2008. Pengaruh Karakteristik Perusahaan Terhadap Pengungkapan CSR dan Dampaknya Terhadap Reaksi Investor. Jurnal Akuntansi dan Keuangan. Vol. 5, No. 2: 245-276.

Widiastuti Harjanti. 2002. Pengaruh Luas Pengungkapan Sukarela dalam Laporan Tahunan terhadap Earnings Response Coefficient (ERC), Disampaikan pada Simposium Nasional Akuntansi V 5-6 September di Semarang.

www.globalreporting.org

www.ncsr-id.org

www.idx.co.id 